\title{
Powerless duplicators of masculine politics
}

\begin{abstract}
In order to gain equal rights with men, women have been struggling for two centuries and, to some extent, this struggle has led them to achieve their rights to elect and to be elected in the political arena. However, even if these efforts are accepted as a significant profit in the aspect of legal processes, it seems that women have not been able to change the structure of male dominant politics as these efforts have not resulted in a positive manner in practice. The aim of this article is to show the place of women in the political structure in Turkey. In order to do this, the article advances a definition of politics as well as short explanations about the perception of politics up to now. After briefly relating some aspects of the phenomenon of social gender, the article explores how women have been restricted by the dominant structure on political platforms.
\end{abstract}

Keywords: politics, male dominant politics, political participation, patriarchal structure, gender.

\section{Introduction}

Politics can be defined from the politicians' point of view as the art of obtaining, or having, a share in power and keeping it but, from the public's point of view, it is a social phenomenon that contains comprehensive and complex topics such as the source of power; the legality of the way in which those in power firstly obtain and then use it; the degree of openness of the political arena (and to whom it is open); the working styles of the mechanisms positioned in this field; and the changeability of the government. Thus far, answers to the question of 'What is politics?' are far from satisfactory and lack objectivity. The responses of those that are looking for answers to the political phenomenon are directly affected by their points of view on politics, the social, economic and cultural position of their community and their expectations of politicians. No doubt there will be differences in respect to the instruments of the political arena and expectations from politics between conservatives, who do not like social relationships and social structure (which is variable) to change, and radical reformists, who wish to rebuild politics and society by using immediate force. On the other hand, politics from a woman's point of view will be to humanise it much more, to bring a female point of view to social events and to efforts to resolve specific problems either by women or at least with the help of women.

Political participation contains the mechanisms of the current political arena and the total sum of the mutual action-reaction movements between those in power and all of the segments and individuals of society. The presence and effectiveness of political participation depends on its becoming a safety valve for the public within a changeable structure which is bounded to rules whose legality is accepted by every social 
community. In societies in which power is regarded as property and its owner is a person or community, it seems impossible to talk about active political participation and participants' effects on those in power - or 'the power'. Active political participation can only truly be realised by the participants' expression of their choices without facing pressure or discrimination in a democratic system in which the authorisation and functional limits of the power are defined; where the working methods and principles of the government and its authorisation and responsibilities are determined and can be regulated; where the maintenance or changing of its functions are bounded by the rules; and where the source and legal basis of the power's political force is the preference of society itself. The acceptance of those in power of society's authorisation to terminate their administration is a sign of the legality of the democratic system. This presence of legality depends on the meaningfulness of activities in political participation, the interest of society in politics and the healthiness of the preferences of the participants, along with the level of their participation.

The political sphere presents a problematic viewpoint in Turkey. The source of the problem is that, after their radical reforms in the economic, social and cultural fields in the early $20^{\text {th }}$ century, the founders of the republic became conservative and were inhibited in catching up with the democratic improvements after World War II in the west which they had used as a model. Democracy is frequently interrupted by traditional coups every ten years, triggered by a community which has no respect for society's democratic demands, on the basis of allegations that society could not 'internalise the reforms' but actually because it was unwilling to give up its government, or power, advantage. The power force, which is supposed to be formed by the free choices of society, is formed by this community's preferences rather than the parliamentary arithmetic after elections, while the directors of the power are forced to account for their past and future applications to this segment of the community rather than the whole community that elected them. Until this community discourages, or is discouraged from, its 'tutelary' role, the building of a political sphere in which an internalised democratic life encourages healthy political participation, without discrimination between men and women, seems impossible.

Actively or passively participating in politics is left to the individual's own preference but, in rearranging the political arena, modern democratic political tools should be moved into this arena while it needs to be kept open for working up mechanisms for all individuals who like to use these tools. Today, concerning individuals who do not, or can not, actively participate in politics, the development of new mechanisms has utmost importance for a democratic society in terms of the building up a more sufficient manner of representation and thus forming a power/government that has no problems with legality.

Other problems in respect to the general structure of politics are political participation being regarded as the casting of a vote every four or five years; the lack of auditing of the government because of the perception that parliament is bound to the government, although it should be vice versa; and the insufficient capability of nongovernmental organisations to audit the government because of their lack of penetration and power. Furthermore, a solution to the problem of the inability to ensure inparty democratic mechanisms in all of the parties, without exception, also needs to 
be found. Until these kinds of general and structural problems are resolved, a female presence in the political arena, with the identity of 'women politicians', forming a solution-seeking context by emphasising the problems of women and the application of a more feminine politics, seems impossible. A feminine politics implies a political concept in which not a single model is dominant, differences are tolerated and, thus, the political arena is defined more widely (Yeğenoğlu, 2007).

It can be stated that women's demand for equal rights with men in many aspects of social life has an evident historical background. In the west, women's struggle for their rights started first of all in the education field. In this historical perspective, which goes back to the $17^{\text {th }}$ century, women have succeeded in making their voices heard, for example in the $18^{\text {th }}$ and $19^{\text {th }}$ centuries, right after the US Bill of Rights (1776) and the French Declaration of Human and Citizen Rights (1789). Through the processes of industrialisation, capitalisation and the nation state, the role and importance of the family has also changed over time, with different political and economic changes. Besides, the intellectual ambience of the American and French revolutions, and their spread of the conception of independence, have formed something of a basis for the feminist movement (Sallan-Gül: citing Jaggar, 2003). Thus, even though women have struggled for many years to obtain their political rights, eventually they might have succeeded in obtaining the right to vote with a movement rising from the grassroots.

In Turkey, women have obtained their political rights under a rather different process than women in the west who obtained them after a grassroots movement triggered and matured by long-lasting struggle. Starting from the end of the Ottoman Empire, Ottoman women, inspired by the struggle of western women for their rights, started this process by voicing aloud their protests through the unions they had formed. Before the republic was declared, women had founded a party named 'Kadinlar Halk Firkası' (Women People's Party), although this was closed after a short period since there was no right in the new constitution for women to vote.

After this party, whose founding members were all women, had been transformed into a union, women, who would have to wait for a period of ten years to be given the political right to vote and to be voted for, could have gained visibility in the parliamentary and political arena in the context of constitutional change by the singleparty government in 1934, which gave women the right to vote and to be voted for. In the fifth parliament, which had eighteen women members, they were represented in a ratio $(4.08 \%)$ that they would never re-attain until 2002 . In the 65 -year period from 1935 to 2002, women could only be represented in the parliament between the changing ratios of $0.61 \%$ (in the 9 th period, 1950; 3 deputies out of 491 ) and $4.36 \%$ (22nd period, 2002; 24 deputies out of 550). This ratio has experienced dramatic change and, at $9.09 \%$, reached the highest value of the republic period after the July 2007 elections (23rd period, 2007; 50 deputies out 550). A discussion on the effects of this $100 \%$ increase, which has a major importance for Turkish democracy and women, can be had under a different study. In such a study, topics could be researched such as ignorance up to now of the 'problem of women'; how women parliamentarians did, or will, perform in making and applying feminist politics; and what they could 
do in actualising or applying women's rights which have gone no further in the legal field so far than theory.

It is known that neither left nor right political parties have given sufficient importance to the issue of women. When it comes to women, even though there are differences in perspectives, it can be stated that the traditional structure has been maintained from Ottoman times. As a result, it is known that women, especially because of the masculine structure of the politics, can not be sufficiently represented and that, in the political process, the parties do not give sufficient importance to the issue of women. Women, who have obtained all kinds of citizenship rights in the view of Turkey's legal structure, are still in the position of spectator since they could not become an active element in the political arena as a result of the treatments they have faced thus far. Besides, and more importantly, another situation which may be observed when looking at the sight, political attitudes and behaviours of women in parliament is that the small number of women who represent all women also perceives politics within the framework of masculine roles. It is observed that the perception that 'politics is a man's job' still continues and that female solidarity has not yet been brought properly to the agenda and has always been kept in a backwards position (Altındal, 2007).

\section{The relationship between politics and gender}

Politics is an effort to regulate relations between the rulers and the ruled, and to deal with conflicting interests by utilising the exercise of power, the management force in a society (Dursun, 2002). In addition:

Politics is a social phenomenon which has been brought about after people started living socially and which has always been active in people's lives and will be so despite following different progress in different countries. (Altındal, 2007: 5)

From the past up to the present, politics have always been regarded as a 'masculine occupation' and women have faced several obstacles in gaining a place in this field. Therefore, the number of women in this field is rather small compared to the number of men. It is possible to argue that this small number is generally caused by the division of labour in society. The reason for this is that the social division of labour does not provide women with roles beyond being 'a good wife, a good housewife and a good mother'; thus, women have great difficulty in surviving in the public sphere. The social division of labour confines women to the private sphere while providing men with the public sphere. In this way, the woman is pushed to a passive and inactive position while the one undertaking the role of decision-maker has been the man. Generally in patriarchal societies, an unchangeable dualist structure has been formed in which women, who are matched with the object, nature, emotion, being nonscientific and the private sphere, always come face-to-face with men, who are matched (in contrast) with the subject, culture, wisdom, science and the public sphere.

However, the point to be noted here is not that both sides praise themselves by imposing a negative meaning on the other but that, within a structure which remains valid today, men are still characterised with positive things while women are attributed with qualities (or inequalities) which encourage their inactiveness and passivity. 
Resulting from this structure, men have confined women to a negative position and have thus been able to maintain their existence permanently and over time, as this has been the case both in present as in the past. This position not only deprives women from taking part in all sorts of activities in a society, but also aims to make them weak and secondary to the power of men, and indeed achieves this. Habermas points out:

The division between the public and private has played a key role in the sense of being a man and woman. The exclusion of women from the political public has been a determining force not only in the sense that only men dominate this sphere as if it were a quota allocated for them but also in the sense that the political public can be formed in a gender-based role because of the nature of the political public and its relationship with the private sphere. (Habermas, 1997: 22).

It is known that there are socio-cultural obstacles to women being equal to men in politics which vary from one country to another, such as their role as traditional housewife and mother, as well as their limited opportunities for education and social security, social pressures and physical impossibilities. It may be observed that a woman who wants to enter politics in this context has to confront such situational and structural obstacles. In the case of Turkey, in the political field, as is the case in all fields - because women are controlled by brothers and fathers in their single lives and by the husband in their married lives - women have always faced gender roles and attitudes which have existed since long before they did and which have been adopted by both genders since the very day they were born. Women internalise the patriarchal structure and assist the obstacles brought about by this structure to their advancement. Therefore, one can argue that women take a subordinate role in performing roles outside the private sphere. The notion that working and non-working women should get married and have children, and that 'work' plays a preventive role for especially working women in performing their domestic roles in a way expected by society, is still being imposed by that society.

Traditional society is carrying on its negative posture towards women. Today, this attitude has been influenced by the positive developments about education and working rights in favour of women, but the public sphere has still more men than women due to the continuation of the traditional division of labour worldwide (Çelebi, 1990). The public sphere is exclusive to men, who use the rights of citizenship, while the public sphere remains closed to women who are forced to be a good housewife, wife and mother in the private sphere. On the basis of society's sexism, women are objects seducing men by their nature and can only be disciplined if they are taken under the control of men, stereotyped as the rational individual in the home. Thus, in addition to performing their roles as 'good wives', women are also praised as 'modest mothers' when they give birth to sons who believe/are made to believe in themselves as the heroes of the future. Those who do not give birth to a son or any child, on the other hand, will be forced into divorce or to putting up with a second and common law wife, regardless of their success in performing their roles as a good wife. In societies where this view is prevalent, women are also restricted from continuing 
their lives peacefully at home as well as facing disapproval when displaying themselves and becoming successful in the public sphere. This role differentiation between the genders also reflects itself in the political field and women conduct politics in a more limited way than men due to these roles being imposed and adopted. Hence, it can obviously be said that there has existed from the very beginning a structure which operates against women in the context of their political participation, and that this structure is still prevalent today.

Kizlloluk comments on the participation of women in political life and states that:

Gender discrimination presents itself as a significant criterion in determining the social position of women and men in Turkish society. Being a man or woman does not only mean having two different genders. This also means having two different positions and different social roles specifically defined with definite boundaries. In this social role division, what a woman has to do is to look after the house and children. The man, on the other hand, is the head of the family. The men have a voice both in family and in social and political institutions. (Kızıloluk, 1994: 215)

That women do not appear in politics is expressed by Kalaycığlu in the following terms:

That a man has higher social-economic resources, more comprehensive contacts with political parties and organizations, causes them to get involved in more intensive political activity than women. (Kalaycıoğlu, 1983: 19)

The general view on this topic in all societies is that women display less interest in politics than men and show themselves (or are able to show themselves) less frequently in the political field compared to men. It is a point not to be ignored that, especially in developing countries, socio-economic and political factors have a direct impact on the political participation of women (K1zıloluk, 1994).

Efforts to ensure equality between men and women have gone through the stages which provide equality between the genders in the realm of participation in the political process. Women in Turkey gained their rights regarding political representation in the 1930s but, even today, they are represented sufficiently in neither the parliament nor in local governments. It is known that the political parties have played a role in this insufficient representation: political parties neither make an effort to question male dominance so as to change the gender-based secondary positions of women, nor do they support the still-weak initiatives that do exist (Ayata, 1998). Similarly, it is very difficult to claim that women's branches of political parties are in a legal and strong position (Sancar-Üşür, 2000).

Sallan-Gul expresses his views on the issue in the following terms:

The gender-based division of labour and women's responsibilities in social life experiences confine them to their family and immediate surroundings. Also, the men-centred political culture and political styles in our country do not support female candidates. Women are just articulated to the politics determined by men and remain objects rather than being founder sub- 
jects. This decreases the political effect of the female movement in the process of ensuring equality between men and women, and delays the transformation of gender-based corporate policies and social relations. (2003: 140-141)

When we consider the appearance of women in political life in Turkey, we can witness that the social division of labour operates quite clearly:

That women's appearance areas have been confined to only being a wife and to motherhood roles in accordance with the traditional divisions keeps them away from politics and leads to an assumption that politics is a field exclusive to men. The efforts of this masculine formation in society to make women 'married to the home' are internalised by women too. (Altındal, 2007: 74)

The roots of this internalisation can be traced back to the early republican times. It is known that, during this period, the enlightenment and the views of liberals such as Rousseau and Locke were prevalent. With this in mind, the new regime opened new 'modest doors' to modernism's well-educated woman with a contemporary appearance, but she regarded 'motherhood' as her first role, entrusted to her by the regime, in bringing up dutiful and patriotic sons for the health and welfare of the indivisible whole country. Here, a western-type nation state patriarchy presents itself. So much so that Halide Edip, an activist female writer of the time, was advocating both women's rights and nationality at one and the same time. Stating that:

\footnotetext{
'A women is first of all an Ottoman and patriotic... the law of the country is a thousand-fold more important and honourable than womanhood law', Halide Edip was apparently internalising the republican nationality between Islamic patriarchy and western patriarchy. (Berktay, 2003: 407)
}

The issue of 'women' in today's Turkey started to develop during the last periods of the Ottoman, 2nd Constitutionalist Period, and gained a different form in the new regime together with Turkish nationality. The new regime imposed on women the burden of ensuring a balance between the modern and the traditional. The pseudo-democratic, liberal and egalitarian political formation has done nothing other than to make women in the new framework subordinate to men, just as they had been in the past. The existence of a Ministry for Women and the Family in the current political decisionmaking mechanism is an example of the role determined for women not changing sufficiently, even at the formal level. The perception that dismisses women and their problems as trivial keeps women away from the public sphere and considers this to be exclusive to men. Arendt expresses it thus:

The public sphere is the world of appearances; individuals should display themselves there. When individuals do not, or cannot, display themselves, no politics can be carried out there. It is necessary to exhibit the differences and to express that they should be in dialogue within the framework of common objectives. (Çakır, 2001: 408) 
In addition to those emphasised by Arendt, it is also necessary to change the existing hierarchical power relations and to generate movement by bringing about a solidaristic and participative common language so as to enable women to raise their voices in the public sphere and display their differences.

As expressed above, a patriarchal mentality enables men to assume decision-making roles in particular in the political field and forms the basis for the masculine nature of politics against women. When viewed from that perspective, it seems difficult for women to attain equal opportunities $v i s-\grave{a}$-vis the power when compared to men in societies like Turkey which have internalised a male-dominant mentality.

The masculine characteristic reflects itself most obviously in the formation of political parties in Turkey. Altındal states that:

Considering the intensity of women in intra-party activities and their situation in the senior staff of the parties, one can observe that they have been, to a large extent, isolated from the political race. (Altındal, 2007: 75)

Agreeing with Çakır, Altındal had earlier pointed out that:

They have become the carrier and even the top producer and practitioner of gender-based ideology. The organisational structure of political parties, their codes and programmes, political advertisements, their way of forming politics, and the stances and postures of the party leaders and party members towards female and male politicians are the concrete indicators of this situation. (2001: 401)

'Female members are not included in the decision-making mechanisms' (Minibaş, 1996: 180) of political party organisations. Women are only appointed either in order to allocate resources to the party they are in, or since they are believed to reach their peers easier during election times. In short, women are forced to act within the boundaries drawn by the 'male' managers of upper positions (Minibaş, 1996).

\section{The position and invisibility of women in the political arena}

The roots of politics date back to the time when human beings adopted a sedentary life. With the formation of manager and managed groups in societies, politics started and so did the power struggle, a natural result of politics. This struggle, still an indispensable phenomenon of social life, has survived to the present and will maintain its existence either legally or illegally unless 'a society without managers', being a utopia, appears.

In a wide sense, politics:

Can be defined as the struggle for acquiring and/or retaining the power mechanism regardless of the type of political system - absolutism, constitutionalism, republic, etc. In a narrow sense, on the other hand, it is the struggle for taking a share from the power within existing legal boundaries by participating in legislation, execution and judiciary, or forming pressure groups such as non-governmental organisations and media and having an impact on them. (Altındal, 2007: 70-71) 
The underlying force behind political struggle in today's political systems is the 'purpose of participating in an assembly', which is accepted as the source of power. Assemblies consist of representatives who have been successful in elections in which more than one political party has participated under equal circumstances; politics is about aiming to gain admission to the assembly through winning the elections with political parties, attending coalitions and carrying out the legal regulations when a majority is not achieved, but where the average allows the formation of a coalition for establishing a government, and applying this regulation by participating in the management or government. The parties not included in the government, on the other hand, serve as the opposition and have to carry out their operations in order to maintain the hope of taking a share of the power at the next election.

\section{Female representation in local governments and parliament}

There are no problems for women in using their rights to vote in elections carried out at local or national level, but problems do arise in the process of women using their rights to be elected. Within the political structure of today's Turkey, it is generally impossible, with the exception of certain beneficial circumstances, for independent candidates and especially for women to gain entry to the national assembly. Candidates can be included on the candidate lists of political parties either through the central survey system of the senior management of the parties or the preferences resulting from province-level elections conducted amongst delegates; consequently, both the inclusion of a candidate on the candidate list and his or her ranking on that list depend firstly on the number of votes gained from party delegates in the province/electoral district and then on the preference of the party leader and/or central management. Due to this practice, which requires above all money, time, networks of strong social relations, several resources and opportunities such as education and experience, it is obvious that women start the political struggle for inclusion on candidate lists and a selectable ranking place from a disadvantageous position right from the very beginning when they stand as candidates at the local or national level.

Until female candidates get past this stage, prove successful in the elections and manage to take their places in parliament or local governments, then the problem of representation continues. The result is that, as of now, the degree of women's representation and the reflection of their demands remains limited in practice to the general political mentality of the parties. Also until recently, the political parties did not place importance on the political participation of women at the local level and it is possible to argue that their demands for election were generally ignored. Even so, one can say that there have been some positive changes in the attitude of the parties towards women, as well as the legal regulations which have been made in recent years, while some initiatives have been undertaken towards the participation of women in political life, even if to some degree.

In Tables 1 and 2 below, set out in accordance with official data from the General Directorate for Local Authorities of the Ministry of the Interior, we provide the results of the local elections carried out in 1999 and in 2004 and the number and rates of female and male representatives in local representation areas. 
Table 1 - The rates of female representatives according to the results of local elections in 1999

\begin{tabular}{|l|c|c|c|c|}
\hline Local representation area & Female & Male & Total & Per cent \\
\hline Mayor & 20 & 3196 & 3216 & 0.6 \\
\hline Member of Provincial Council & 44 & 3078 & 3122 & 1.4 \\
\hline Councillor & 541 & 33543 & 34084 & 1.6 \\
\hline
\end{tabular}

Source: General Directorate for Local Authorities of the Ministry of the Interior, KSSGM, 2007.

Table 2 - The rate of female representatives according to the results of local elections in 2004

\begin{tabular}{|l|c|c|c|c|}
\hline Local representation area & Female & Male & Total & Per cent \\
\hline Mayor & 18 & 3207 & 3225 & 0.56 \\
\hline Member of Provincial Council & 57 & 3151 & 3202 & 1.78 \\
\hline Councillor & 817 & 33660 & 34447 & 2.37 \\
\hline
\end{tabular}

Source: General Directorate for Local Authorities of the Ministry of the Interior, KSSGM, 2007.

In comparing Tables 1 and 2 , it is not possible to regard the small increases in the number of female members in city and provincial councils in that five-year period and consider it a decisive positive change. It may also be observed that the level of female representation in local governments $-0.56 \%$ and $2.37 \%$ - is even lower than that of $1935(4.08 \%)$, when women participated in parliament for the first time. This does not have the characteristic of representation.

In local governments after 1980, the number of female members of council in particular has increased when compared to the past. For instance, 29 of the total of 807 members of council in Istanbul Metropolitan Municipality and its twenty sub-municipalities, and 19 of the total of 171 members of council in Ankara Metropolitan Municipality and its seven sub-municipalities, are women. (Koray, 1991: 36)

Apparently supporting this view, Kümbetoğlu emphasises that:

The figures show that women have such little participation even in the three big cities. (Kümbetoğlu, 2001: 273) 
Alkan accounts for the representation of women at a lesser rate in local governments than in the national government to be the result of:

The commoditisation of both urban land and urban goods and services, and the transformation of profits over these lands into areas that could be shared out seriously during the era following 1980.

He also argues that:

Due to local politics and governments not being considered as a service area but rather one in which unearned income is shared, it is regarded as usual when women, who have very limited contacts with occupational groups amongst which the ownership of individual property from which unjustified benefits and unearned income may be obtained is produced and distributed, are indirectly excluded from representation. (Alkan, 2004)

According to Alkan, it is necessary to focus on three more reasons in order to comprehend the issue better. One of these is the symbolic nature of women in corporate politics; the second is the very limited nature of women's social activity; and the third is the exclusion of women's organisations from local areas of interest until recently (Alkan, 2004).

Uras also agrees with Alkan that local governments are not considered as service areas but rather ones for the sharing out of unearned income, and states that:

It is obviously necessary to eliminate state-centred generation and distribution mechanisms of unearned income. The purchase of votes is becoming especially widespread in local elections via a raising of the hopes for individual emancipation based on promises of a share in unearned income from cities. (2007)

In addition to all the factors which inhibit political participation generally, the pressure of traditional society, especially in small towns, is an extra negative factor in the participation of women in local governments and in the level of their representation in these regions.

These problems in the case of Turkey are experienced similarly in even the most democratic societies worldwide (although there are regional variations). The number of women and the rate of their representation in political areas is low since those women who do actively engage in politics within political parties can, most of the time, find themselves a place on candidate lists only in electoral districts where their chances of being elected stand low, and even then only from lower ranking positions. When considering political participation across the world, it can be said that women have a 99 per cent right to passive political participation; but corresponding active participation is not provided and so the rate of women who are active in political life is quite low and they remain a minority, especially in political decision-making mechanisms (Çitçi, 1992). 
Table 3 - The number and percentage of women deputies in the Turkish Grand National Assembly

\begin{tabular}{|c|c|c|c|c|}
\hline $\begin{array}{l}\text { Legislative } \\
\text { period }\end{array}$ & Election year & $\begin{array}{l}\text { Total no. of } \\
\text { deputies }\end{array}$ & $\begin{array}{c}\text { No. of women } \\
\text { deputies }\end{array}$ & $\begin{array}{c}\text { Percentage of } \\
\text { women deputies }\end{array}$ \\
\hline 5 & 1935 & 441 & 18 & 4.08 \\
\hline 6 & 1939 & 465 & 15 & 3.23 \\
\hline 7 & 1943 & 484 & 16 & 3.31 \\
\hline 8 & 1946 & 497 & 9 & 1.81 \\
\hline 9 & 1950 & 491 & 3 & 0.61 \\
\hline 10 & 1954 & 535 & 4 & 0.75 \\
\hline 11 & 1957 & 602 & 8 & 1.35 \\
\hline 12 & 1961 & 449 & 3 & 0.67 \\
\hline 13 & 1965 & 455 & 8 & 1.76 \\
\hline 14 & 1969 & 450 & 5 & 1.11 \\
\hline 15 & 1973 & 456 & 6 & 1.31 \\
\hline 16 & 1977 & 455 & 4 & 0.88 \\
\hline 17 & 1983 & 399 & 12 & 2.93 \\
\hline 18 & 1987 & 450 & 6 & 1.34 \\
\hline 19 & 1991 & 450 & 8 & 1.77 \\
\hline 20 & 1995 & 550 & 13 & 2.36 \\
\hline 21 & 1999 & 550 & 22 & 4.00 \\
\hline 22 & 2002 & 550 & 24 & 4.36 \\
\hline 23 & 2007 & 550 & 50 & 9.09 \\
\hline Total & $\begin{array}{l}19 \text { election } \\
\text { periods }\end{array}$ & 9279 & 234 & 3.86 \\
\hline
\end{tabular}

Source: Balay, 1996: 79. (Note: State Institute of Statistics (DIE) data was added to the Table for periods 21 and 22, and belgenet.net data for period 23.

In assessing Table 3, showing the numbers of male and female representatives in the Turkish parliament over time, it can be seen that the female representation rate was very low until the mid 1990s: following the 5th legislative period, in which women were represented by $18 \mathrm{MPs}$ at a rate of $4.08 \%$, the rate decreased to a low of 0.61 in the $9^{\text {th }}$ period, when there were just three women MPs. The initial figure was not surpassed until the 22nd legislative period, when there were 24 MPs $(4.36 \%)$; and, in spite of a $100 \%$ rise in the 2007 elections, even this level of representation 
did not mean a remarkable increase in itself in terms of the overall numbers of women representatives. Kovanlikaya (1999) points out that this low rate of the representation of women in the Turkish parliament, where the right to elect and be elected was granted to women before many European countries, arises from the nature of the democratic regime as well as from gender-based applications in the use of political channels.

Table 4 - Female representation rates in the national parliaments of European countries: 2006

\begin{tabular}{|c|c|c|c|}
\hline Country & Total MPs & Female MPs & $\begin{array}{l}\text { Female representation } \\
\text { rate } \%\end{array}$ \\
\hline Germany & 614 & 195 & $31.8 \%$ \\
\hline Albania & 140 & 8 & $5.7 \%$ \\
\hline Austria & 183 & 59 & $32.2 \%$ \\
\hline Belgium & 150 & 53 & $35.3 \%$ \\
\hline Bosnia and Herzegovina & 42 & 6 & $14.3 \%$ \\
\hline Czechoslovakia & 200 & 31 & $15.5 \%$ \\
\hline France & 577 & 70 & $12.1 \%$ \\
\hline Netherlands & 150 & 55 & $36.7 \%$ \\
\hline UK & 646 & 128 & $19.8 \%$ \\
\hline Ireland & 166 & 22 & $13.3 \%$ \\
\hline Spain & 350 & 126 & $36.0 \%$ \\
\hline Sweden & 349 & 165 & $47.3 \%$ \\
\hline Switzerland & 200 & 50 & $25.0 \%$ \\
\hline Italy & 630 & 109 & $17.3 \%$ \\
\hline Iceland & 63 & 19 & $30.2 \%$ \\
\hline Latvia & 141 & 29 & $20.6 \%$ \\
\hline Luxembourg & 60 & 14 & $23.3 \%$ \\
\hline Macedonia & 120 & 34 & $28.3 \%$ \\
\hline Hungary & 386 & 41 & $10.6 \%$ \\
\hline Malta & 65 & 6 & $9.2 \%$ \\
\hline Norway & 169 & 64 & $37.7 \%$ \\
\hline Poland & 460 & 94 & $20.4 \%$ \\
\hline Portugal & 226 & 44 & $19.5 \%$ \\
\hline
\end{tabular}




\begin{tabular}{|l|c|c|c|}
\hline Country & Total MPs & Female MPs & $\begin{array}{c}\text { Female representation } \\
\text { rate \% }\end{array}$ \\
\hline Romania & 332 & 38 & $11.4 \%$ \\
\hline Slovakia & 150 & 30 & $20.0 \%$ \\
\hline Slovenia & 90 & 11 & $12.2 \%$ \\
\hline Greece & 300 & 40 & $13.3 \%$ \\
\hline
\end{tabular}

Source: Table developed with data from The Implementation of Quotas: European Experiences The Global Database of Quotas for Women, a Joint Project of International IDEA and Stockholm University 2006.

When considering Table 4's data on the representation of women MPs in a selection of European countries in 2006, it can be seen that the rate of the representation of women in the Turkish parliament following the 2002 elections was, at $4.35 \%$, below half the rate in Malta, the lowest among the European countries. Even though this figure rose to $9.09 \%$ in the most recent 2007 elections, it has still not reached the level of Malta, which was $9.2 \%$. In the worldwide context, the representation of women in parliaments is seen to be notably low, except in Scandinavian countries.

To conclude, the division of labour on a gender basis is determined by the masculine domination of the traditionally-structured Turkish society and, as a natural consequence of this, the political arena is reserved for men while politics is considered a 'man's job'. Consequently, the idea advocating that women's involvement in this arena is unnecessary is still widespread. In accordance with the division of labour based on social gender and the position of the limited number of women in politics, the regulations and programmes of the political parties, which explicitly describe an exclusionary approach, are determined by men and, as a result, women politicians in the political race encounter an exclusionary manner and behaviour from men. Female activities in political life thus arrive at a deadlock right from the very beginning.

\section{Women in political party mechanisms}

Turkish society still continues to demonstrate a structure in which patriarchal mindset and patterns are dominant. Men sustaining the hegemony over women that is present in every aspect of life, display behaviour in favour of the present network of relations that are based on inequality. Politics as well depicts itself in a way in which this inequality is legitimated. (Altındal, 2007: 74)

Patriarchal structure privileges men, shapes political theory and practice and, in this masculine structure, women fail to gain a seat.

When the structure of political parties in Turkey is observed, and both the involvement of women in activities within the parties and their representation in adminis- 
trative positions are taken into account, it may be observed that they are to a great extent excluded from the political race. According to Çakır, these parties:

Have been the promoters of sexist ideology and even the most important producers and implementing bodies at the institutional level. Institutional structure, party regulations and programmes, political advertising and the manner of making policies of the political parties, as well as the way political leaders and members view and evaluate female and male politicians, are concrete indicators of this situation. (2001: 401)

In political party organisations, 'female members are excluded from the decisionmaking mechanisms' (Minibaş, 1996: 180); women are appointed either to provide resources to the party that they are involved in or, especially during political campaigning, to facilitate an approach to women in order to canvass. In sum, women are forced to act within the boundaries defined by 'male' directors in the primary positions (Minibaş, 1996). Thus, women are passivated in a masculine politics and cannot take an active part in political life. The patriarchal structure that matches men with effective, objective and decision-making positions, and women with inactive definitions such as passive and sensual, inhibits women from decision-making structures and places them in secondary positions.

As a result of this manner, when women, who are considered differently from men within the political parties, are appointed, they are subject to a manner that suspends them from active political life and, even when they manage to take part in this arena, they are passivated by their appointment to issues like education, family and health and not to primary issues such as economy, defence and foreign politics. (Altındal, 2007: 75)

It is well-known that, after the adoption of the multi-party system in Turkey, except for a couple of special cases and temporary situations, women have never taken part in decision-making bodies such as the vice presidency, party caucus presidency or provincial presidency of any political party that has had a sustained life in Turkish politics. Within today's political structure, it is difficult for women to be promoted to these positions and, what is more, their involvement even in secondary positions seems to be limited. It would not be an exaggeration to state that women members, having accepted this situation, having undertaken without objection such secondary roles as parliamentary 'speaker' or 'watchdog' and even having internalised these roles, are presented by the administrators as 'party windows'. The presence of women in parliament, in line with their appraised roles in society, are limited within what can be considered women's specialist areas such as education, health and the family and some extensions of these areas. This is not accepted as embodying sufficient justification for viewing them as having an exactly equal status with male parliamentarians. Minibaş points out that women:

Even if their expertise allow them... are not appointed to positions in commissions regarding national defence, internal affairs and the economy that are in the primary interest of the country's administration. (1996: 180) 
All of these demonstrate explicitly that men exert a strict control mechanism on women's attempts to become active in politics. It is even possible to assert that women are subject to a blockade that starts from the family and extends to the political arena. Women were not represented in the first parliament convocated during the Independence War, nor in those called after the establishment of the Republic, and indeed women were never represented at this level until the 1930s. Even after that date, the political arena, which has been viewed from the beginning as belonging uniquely to men throughout the historical process, has hindered women's egalitarian representation, reinforcing the already-present inequalities. When this is examined in detail, it becomes apparent that women have either stayed away, considering this arena as masculine, or else have carried out a mannish politics by disregarding the issue of women. In the case of Turkey, it would not be mistaken to mention Tansu Çiller as the most striking example of this second attitude towards politics. Tokgöz, while stating that:

Çiller as the female prime minister, her dressing up in tailleur just like Margaret Thatcher, exprime minister of Great Britain, her walking at the double, her shaking hands with people, her kissing women of every background, and her smiling could only be possible with a detailed analysis of whether she embodies feminine or masculine assets (Tokgöz, 1998: 563)

supports the opinion that regards Çiller as far from the reality of 'effeminate politics'. In fact, Çiller had received the majority of her votes from women following her populist discourses of 'mothers, sisters' until she became the prime minister. Nevertheless, it is well-known that she did not make policies or present projects in favour of women during the times she was a parliamentarian, a minister and even the first female Prime Minister of the Turkish Republic, just like many male politicians. From this perspective, Çiller's insensible manner towards the 'woman problem' estranged her from 'the profile of a woman who is expected to ameliorate women's conditions' regarding politics and which, moreover, caused the loss of her prime ministerial position as a result of the positions taken by women electors in the subsequent periods. Ağduk-Gevrek, in line with this argument, points out that she:

Had caused her party to move from first position to fifth in five years. The party, within itself, was confronted with 'blood loss' and, outside it, with a loss of votes and public opinion (Ağduk-Gevrek, 2000: 303).

\section{Conclusion}

In the modern state system, in which it is essential that power be delegated without exercising force, the primary tool for obtaining and using power is political parties. In addition, the involvement of those who have a bearing upon politics in the political arena on a mass basis, through the opening up of the political arena to political parties following the emergence of the modern state and participation in political parties in order to be encompassed within the power struggle, is particularly recent. It can be asserted that political participation accommodates essentially unequal relationships. In this way, a hierarchy is created among two groups: namely, those who 
are affected by the decisions; and those who seek to prejudice them in their own favour (Uysal, 1984). It can be stated that both share a common aim of affecting the political authority which is intrinsic to both narrow or wide, as well as to voluntary or motivated, forms of political participation (Özbudun, 1975).

All behaviour of an individual that affects the functioning or the decisions of governmental bodies both at the central and the local level; all behaviour, whether contemplated by himself or others, legal or illegal, successful or unsuccessful, fall within political participation behaviour. (Çukurçayır, 2000: 31)

It is known that political participation is actualised primarily through political parties. Political parties are prerequisites for democratic regimes and they may be considered as institutions that are the main means of political participation. For this reason, parties are regarded as organisations that make democracy dynamic, tasked as they are with activating the social actors, whether individual or societal ones. Hence, it is important that political parties enable participation as a means of integrating citizens with the system (Özkul, 2005). According to Özkul:

In this way alone, democracy becomes an 'equilibrium regime' in which conflicts between the dominant class and the masses are moderated.

The mediators for this moderation are political parties. For this reason, the parties have to be accepted as vital for democracy. Today, political parties have become the main channels for political participation (Özkul, 2005: 132).

Talasli states:

Political parties are the main elements and the primary dynamic strengths of political life in democratic and pluralist systems. Having functions such as enabling the integration and orientation of different interests and calls, acting as a bridge between the masses and the political power, and administrating and governing after coming into power, political parties are the primary channels of political participation and, in this sense, they should be tasked with increasing the rate of female participation in politics. (1996: 193-194).

\section{Altındal comments:}

Political parties engaged with women's participation in politics only when concepts like 'democracy', 'human rights' and 'equality' started to become established in every aspect of social life. Only after that has the place of women in politics, shaped as it is by the dominant masculine mindset, has turned into a issue for debate. (Altındal, 2007: 64)

Women, who did not have a place even in domestic decision-making mechanisms for centuries, are known to have become conscious of standing up for their rights and getting involved in the class struggle, and have striven for many rights ranging from demands for equal pay to property rights and enfranchisement. However, it can be indicated that women's participation in political parties and their coming to 
the fore within decision-making mechanisms only dates back to the second quarter of the $20^{\text {th }}$ century (Minibaş, 1996).

It can be asserted from women's low rate of representation in parliament and in local government that the political parties, addressing women's right to vote in order to receive their votes, and supporting women on this issue, do not possess the same sensibility when it comes to women's right to stand for election. It can be further asserted that the political parties do not support women in active political life.

Another important issue in women's participation in politics is that the only considered solution is regarded as an increase in the number of women politicians. However, in addition to the need for an increase in this number, what is more important is to enable the qualitative representation of women who are aware of the 'woman problem'; as Yeğenoğlu puts it:

Not women's representative participation in politics but a 'feminisation of politics' (Yeğenoğlu, 2007).

The political presence of women who are neither yet conscious nor sensitive of the need to articulate the problems of women will bring about the re-enforcement of a masculine politics and will, from the beginning, hinder radical change in support of women.

Subsequent to the establishment of the Republic, neither a left-wing nor a rightwing party has ever paid sufficient attention to the 'woman problem'. Even though they have diverse standpoints as regards politics, when it comes to this 'problem', the political parties have stuck to their regard for a woman-less politics. It is expected of women either that they take part in mannish politics or that their participation in the political arena lies in terms of 'articulating' to the party the concerns of the women's group, which is considered to be sufficient for women. In all the political parties, regardless of their ideological differences, it is striking that the patriarchal structure and the traditional division of labour are maintained and that women themselves, putting their 'female identity' after their 'party identity' in this structure, except for making a couple of criticisms once in a while, consider their image to be sufficient in the political spectrum (Çakır, 2001).

In the Turkish political structure, the consequence of a male-dominated structure has been that women have become distanced from active politics. Thus, instead of becoming the main political actors, women are able to show themselves only in a secondary function which is dependent on men and whose politics are geared towards men. The consequence is that the traditionalist understanding which confines women within the home in accordance with the social division of labour thereby maintains its sexist approach. Thus, women willing to take part in politics seek a safe place for themselves within a system which hinders their being active subjects, downplays their identities in relation to their party identities and entraps them within a political spectrum in which no policies are produced for women. Some women in this space, where there is no place reserved for women, make their presence visible by becoming involving in mannish politics, as is also seen in Tansu Çiller's case, without paying attention to their identities. However, whether the content of this visibility is pro- 
mising for the awaited solutions for the problems of women is dubious. In this regard, even though the primary problem is to increase the number of women in order to pursue an efficient political policy, it is evident that the solution is not limited to the quantity; even if women, who are far from sensitive of the need to act in solidarity and who are conducting their politics in a mannish way, achieve half the seats in parliament, this will not solve the existing problems. Thus, there is the necessity for a qualified profile of women.

In order to reflect in the political arena the equilibrium present in society between women and men, it is above all necessary that social, economic and cultural barriers with a bearing on women's participation in both the private space and the public arena be removed and that the political arena be re-organised. It does not seem possible to speak of a functioning representation and a real democracy unless women are represented, in general, i.e. in all aspects of life, equally with men and, in particular, sufficiently in the political arena and on the basis of their own identities. Departing from women's only problem, in all social spaces, of the need not to be confined within the domestic space, and in order not to be 'women on the slope of politics at the summit', it is necessary to restructure the political arena in a way that enables women to raise their voices and to become engaged in politics for women. The feminising of politics should be regarded as the primary condition for assimilating a functioning democracy as lifestyle. Only on the condition that such a space emerges in Turkey can we shift from today's stereotypical woman, which is not able to achieve power in politics, to a protagonist female typecast.

\section{References}

Ağduk-Gevrek, M (2000) Cumhuriyetin Asil Kızlarından ‘90’Ların Türk Kızlarına... 1990’larda Bir 'Türk Kızı': Tansu Çiller, Vatan Millet Kadınlar, Der. Ayşe Gül Altınay İletişim Yayınları: İstanbul, pp. 280-307.

Alkan, A (2004) 'Yerel Siyaset Kadınlar İçin Neden Önemli?' Birikim Dergisi 179: 71-77.

Altındal, Y (2007) Kadının Siyasal Katılımı Bağlamında Partilerin Kadın Kollarının Sosyolojik Açıdan Değerlendirilmesi Adnan Menderes Üniversitesi Sosyal Bilimler Enstitüsü, Yayınlanmamış Yüksek Lisans Tezi Aydın.

Ayata, A (1998) 'Laiklik, Güç ve Katılım Üçgeninde Türkiye'de Kadın ve Siyaset' Derl: Ayşe Berktay 75 Yılda Kadınlar ve Erkekler, Tarih Vakfı Yayınları: İstanbul, pp. 237-284.

Balay, B (1996) Kadınların Siyasal Katılma Davranışları Gazi Üniversitesi Sosyal Bilimler Enstitüsü, Halka İlişkiler ve Tanıtım Anabilim Dalı, Yayınlanmamış Yüksek Lisans Tezi: Ankara.

Berktay, F (2003) 'Osmanlı'dan Cumhuriyet'e Feminizm' Tarihin Cinsiyeti, Metis Yay, İstanbul, pp. 88-111.

Çakır, S (2001) 'Bir'in Nostaljisinden Kurtulmak: Siyaset Teorisine ve Pratiğine Cinsiyet Açısından Bakış’ Yerli Bir Feminizme Doğru Derl: A. İlyasoğlu and N. Akgökçe, Sel Yayınc1lık: İstanbul, pp. 385-422. 
Çelebi, N (1990) Kadınlarımızın Cinsiyet Rolü Tutumları Sebat Ofset: Konya.

Çitçi, O (1992) 'Kadınlar ve Siyasal Katılma' Bülten Türk Demokrasi Vakfı Yayın Organı C: $1 \mathrm{~S}:$ 11: Ankara, pp. 21-23.

Çukurçayır, A (2000) Siyasal Katılma ve Yerel Demokrasi Yargı Yayınevi: Ankara.

Dursun, D (2002) Siyaset Bilimi Beta Yayıncıl1k: İstanbul.

Habermas, J (1997) Kamusallığın Yapısal Dönüşümü, Çev. Tabı1 Bora, M, İthat Sancar, İletişim Yayınları: İstanbul, p. 22.

Kalaycıŏlu, E (1983) Karşılaştırmalı Siyasal Katılma, Siyasal Eylemin Kökenleri Üzerine Bir Araştırma İstanbul Üniversitesi SBF Yay: İstanbul.

Koray, M (1991) Günümüzdeki Yaklaşımlar Işı̆̆ında Kadın ve Siyaset Tüses Yayını: İstanbul.

Kovanlıkaya, Ç (1999) Türkiye'de Politik Alanda Kadınlar ve Kadın Politikası Mimar Sinan Üniversitesi, Sosyal Bilimler Enstitüsü, Yayınlanmamış Doktora Tezi: İstanbul.

Kızıloluk, H (1994) Temsil Açısından 1960 Sonrası Türk Siyasal Yaşamının Sosyolojik Çözümlemesi Mimar Sinan Üniversitesi, Sosyal Bilimler Enstitüsü, Yayınlanmamış Doktora Tezi: İstanbul.

Kümbetoğlu, B (2001) 'Kentsel Alan ve Yerel Yönetimlerde Toplumsal Cinsiyet' Yerli Bir Feminizme Doğru Derl: A. İlyasoğlu and N. Akgökçe, Sel Yayıncılık: İstanbul, pp. 259-282.

Minibaş, T (1996) 'Siyasal Partiler Yelpazesinde Kadının Konumu’ Derl: N. Arat, Say Yayınlar1: İstanbul, pp. 173-189.

Özbudun, E (1975) Türkiye'de Sosyal Değişme ve Siyasal Katılma AÜHF Yayınları, No. 363: Ankara.

Özkul, M (2005) Yarı Modern Toplumda Sivil Toplum ve Demokrasi Sakarya Üniversitesi Sosyal Bilimler Enstitüsü Sosyoloji Anabilim Dalı Yayınlanmamış Doktora Tezi: Sakarya.

Sallan-Gül, S (2003) 'Dünyada ve Türkiye'de Feminizm ve Kadın Hareketi' Çağdaş Kamu Yönetimi I, Nobel Yayınları: Ankara, pp: 125-150.

Sancar-Üşür, S (2000) 'Siyasal Süreçlere Katılımda Kadın-Erkek Eşitliği’ Kadın-Erkek Eşitliğine Doğru Yürüyüş; Eğitim, Çalışma ve Siyaset TÜSİAD Yayınları: İstanbul, pp. 197-262.

Talaslı, G (1996) Siyaset Çıkmazında Kadın Ümit Yayıncılık: Ankara.

The Implementation of Quotas: European Experiences Global Database of Quotas for Women joint project of International IDEA and Stockholm University, 2006.

Tokgöz, O (1998) 'Doğru Yol Partisinin Kadına Yönelik Söylemi (1982-1995)' 20. Yüzyıl Sonunda Kadınlar Ve Gelecek Der. Oya Çiftçi, Todaie Yayını: Ankara. 
Uras, U (2007) Siyasi Yenilenme Perspektifi İstanbul www.İndymedia.org.tr Erişim Tarihi, 8 January.

Uysal, B (1984) Siyasal Katılma ve Katılma Davranışına Ailenin Etkisi Orta Doğu Amme Enstitüsü Yayını: Ankara.

Yeğenoğlu, M (2007) Ne Şam’in Şekeri, Ne Erkeğin Biylğl radikal.com.tr/ek_haber erişim tarihi. 15 April 2007.

www.kssgm.gov.tr, 2007. 